Acta horticulturae et regiotecturae 1

Nitra, Slovaca Universitas Agriculturae Nitriae, 2013, s. 4-9

\title{
CHANGES IN CONCENTRATIONS OF MONOVALENT BASIC CATIONS IN THE WATER OF THE ČARADICE STREAM ZMENY KONCENTRÁCIÍ JEDNOMOCNÝCH BÁZICKÝCH KATIÓNOV VO VODE VODNÉHO TOKU ČARADICKÝ POTOK
}

\author{
Jaroslav NOSKOVIČ, Mária BABOŠOVÁ, Jana PORHAJAŠOVÁ, Eva CANDRÁKOVÁ \\ Slovak University of Agriculture in Nitra, Slovak Republic
}

\begin{abstract}
In the years 2005-2010, the changes in concentrations of monovalent basic cations in the Čaradice Stream were evaluated depending on the time and place of sampling in its longitudinal profile. Results show that the average concentration of $\mathrm{Na}^{+}$in the whole period was $14.75 \mathrm{mg} . \mathrm{dm}^{-3}$. Its share in the total amount of monovalent basic cations of $\mathrm{Na}^{+}$and $\mathrm{K}^{+}$in the whole reference period was $76.32 \%$. The mass ratio of $\mathrm{Na}^{+}: \mathrm{K}^{+}$in the whole period was $3.34: 1$. Depending on the time of sampling, the lowest average sodium concentrations of the whole period were recorded in the spring season with the minimum average in March. The highest average concentration of the whole reference period was recorded in September. Depending on the sampling site, the minimum average concentration was recorded in a forest ecosystem and an ecosystem of permanent grassland, and the maximum average concentration in the village Kozárovce. Using the analysis of variance, we detected a statistically significant effect of all three qualitative factors (year, month and place of sampling) on the change of concentration. According to the Regulation of the Government of the Slovak Republic No. 269/2010 Coll., the $90^{\text {th }}$ percentile values of this indicator are lower than the recommended value. The average concentration of potassium in the whole reference period was $4.54 \mathrm{mg} . \mathrm{dm}^{-3}$. The share of $\mathrm{K}^{+}$in the total amount of monovalent basic cations in the whole period reached $23.68 \%$. The lowest average concentrations of the whole period were usually found in the spring season, with the minimum value in March. The maximum average concentration of the whole reference period was recorded in July. Similarly to $\mathrm{Na}^{+}$, the lowest average concentration of $\mathrm{K}^{+}$was detected in a forest ecosystem and the highest one in the village Kozárovce. The effect of seasonality on the dynamics of $\mathrm{Na}^{+}$and $\mathrm{K}^{+}$concentrations during the period was not detected. Using the analysis of variance, we found a statistically significant effect of all three qualitative factors (year, month and place of sampling) on the change of concentration. In the Regulation of the Government of the Slovak Republic No. $269 / 2010$ Coll., the recommended value for potassium is not specified. The discharge rate significantly affected the changes in concentrations of $\mathrm{Na}^{+}$and $\mathrm{K}^{+}$in the stream.
\end{abstract}

Keywords: stream, monovalent basic cations, sodium, potassium

There is an equal share of sodium and potassium in the Earth's crust, they represent $2.5 \%$ of it. However, in groundwater and surface water, the concentration of sodium almost always exceeds the concentration of potassium. This can be explained by the fact that soil minerals adsorb more potassium ions than sodium ions and that potassium is an important nutrient for plants (in plant ashes, the mass ratio of $\mathrm{K}: \mathrm{Na}$ is $100: 1$ ) (Hruška et al., 2006; Pitter, 2009, Orolínová, 2009). They are released into water during the weathering of certain aluminosillicates (Töllgyessy et Melichová, 2000). Another natural source of sodium is the exchange of calcium and sodium ions that occurs when certain argillaceous minerals come into contact with water (Pitter, 2009, Pačes, 2011). In groundwater and surface water, sodium is usually found in the range of $1-100 \mathrm{mg}^{-\mathrm{dm}^{-3}}$ (Kašiarová, 2002). Anthropogenic sources of sodium and potassium include industrial waste water that contains chloride or sodium sulphate, applied potassium fertilizers and sewage (Töllgyessy and Melichová, 2000; Pitter, 2009). The $\mathrm{Na}^{+}$: $\mathrm{K}^{+}$ratio is usually within the range from $10: 1$ to $25: 1$. Monovalent basic cations of $\mathrm{Na}^{+} \mathrm{a} \mathrm{K}^{+}$found in water are not hygienically significant (Pitter, 2009).

\section{Material and methods}

The Čaradice Stream rises in the mountain range Pohronský Inovec at the southern foot of the Drienok Mountain (751.1 MASL) in the altitude of 600 MASL. The stream crosses the regions of Zlaté Moravce and Levice. It is a right-sided tributary of the Hron River and it is $11.1 \mathrm{~km}$ long. The level water reservoir Priehrada was built above the municipality of Kozárovce, it is located between the municipalities of Čaradice and Kozárovce. Its main function lies in irrigation and sport fishing. On the right side, the largest tributary of the Čaradice Stream is the Svätý potok Stream (coming from the area near the Sejov Mountain, 295.2 MASL), on the left side, there are only some short tributaries. The water flow direction of this stream is mostly north-south; in the lower reaches, it changes to south-east. The Čaradice Stream flows into the Hron River below the municipality of Kozárovce, in the so called area of The Slovak Gate in the altitude of approximately 174 MASL. Hydrographical conditions show that the Caradice Stream belongs to an upland-lowland habitat with a typical nival-pluvial runoff regime with maximum discharge in March and minimum discharge in September. According to the characteristic 
of geological bedrock, the interest area is an extensive old volcanic structure that was formed during several periods of volcanic activity alternating with periods of destruction and denudation of volcanic complexes. This structure contains alternating neovulcanite formations of andesitic, rhyolitic and basaltic type. Apart from volcanic rocks, there is also thrust sheet limestone (Konečný, 1998).

The observed area is located in a warm region and a slightly dry subregion. The average temperature reached $9.1^{\circ} \mathrm{C}$ in $2005,9.7^{\circ} \mathrm{C}$ in $2006,8.9^{\circ} \mathrm{C}$ in $2007,9.4^{\circ} \mathrm{C}$ in $2008,9.8^{\circ} \mathrm{C}$ in 2009 and $10.03^{\circ} \mathrm{C}$ in 2010 . The annual average precipitation reached $711.4 \mathrm{~mm}$ in 2005, $842.7 \mathrm{~mm}$ in $2006,569.8 \mathrm{~mm}$ in $2007,679.7 \mathrm{~mm}$ in 2008, 684.4 $\mathrm{mm}$ in 2009 and $687.7 \mathrm{~mm}$ in 2010 (source: the precipitation station Kozárovce).

In the upper part of the stream basin, there are forest ecosystems and permanent grasslands. A larger part of the stream crosses agroecosystems of farming cultures on arable land. The dominant soil types in the interest area include brown earth, brown soil, chernozem, fluvisol and mollic fluvisols.

From the aspect of agricultural production, this region belongs to corn and beet producing areas. Local arable farming is oriented on production of cereals (winter wheat, winter rye, spring barley, corn grown for grain and corn grown for silage), perennial fodder crops (alfalfa) and oleaginous plants (winter oilseed rape, sunflower). Animal husbandry is oriented on beef cattle farming. The cultivated land located in the vicinity of the stream belongs to the land cadastre of the agricultural cooperative Polnohospodárske podielnické družstvo Volkovce.

During the reference period, the following amounts of these industrial fertilizers were applied: urea ( $\mathrm{N}=46 \%)$, DAM $390(\mathrm{~N}=30 \%), 200 \mathrm{~kg}^{-h^{-1}}$ of NPK $15: 15: 15(\mathrm{~N}=12 \%$, $\left.\mathrm{P}_{2} \mathrm{O}_{5}=19 \%, \mathrm{~K}_{2} \mathrm{O}=19 \%\right), 350 \mathrm{~kg} \cdot \mathrm{ha}^{-1}$ of LAV ( $\left.=27 \%\right), 250$ kg.ha ${ }^{-1}$ of DASA ( $\left.=26 \%, S=13 \%\right)$. The average amount of nitrogenous fertilizers was $138 \mathrm{~kg} \cdot \mathrm{ha}^{-1}$.year ${ }^{-1}$, the average amount of phosphate fertilizers was $39 \mathrm{~kg} \mathrm{ha}^{-1}$.year ${ }^{-1}$ and the average amount of potassium fertilizers was $6.01 \mathrm{~kg} \cdot \mathrm{ha}^{-1}$. year ${ }^{-1}$. In the autumn of 2008, ground limestone was applied in the amount of 2 t.ha $^{-1}$. As an organic fertilizer, manure was applied under the root crops in the amount of 40 t.ha $^{-1}$.year ${ }^{-1}$ (source: PPD Volkovce).

Water samples from the Čaradice Stream were taken regularly in the second decade of a month in the years 2005-2010. The location of sampling sites in the longitudinal profile of the stream was chosen very carefully. This way, the results enabled us to evaluate the effect of forest, agricultural and urban ecosystems as well as other real sources of pollution on the quality of water in said stream. Samples were taken from six sampling sites marked 1-6. They were always taken from the middle of the main streamline:

1. sampling site - below the forest ecosystem Pohronský Inovec, $48^{\circ} 22^{\prime} 56^{\prime \prime} \mathrm{N}$ and $18^{\circ} 29^{\prime} 73^{\prime \prime} \mathrm{E}$;

2. sampling site - above the Čaradice municipality, $48^{\circ} 21^{\prime}$ $91^{\prime \prime} \mathrm{N}$ and $18^{\circ} 30^{\prime} 53^{\prime \prime} \mathrm{E}$;

3. sampling site - below the Čaradice municipality, $48^{\circ} 21^{\prime}$ $35^{\prime \prime} \mathrm{N}$ and $18^{\circ} 30^{\prime} 55^{\prime \prime} \mathrm{E}$;

4. sampling site - in front of the water reservoir, $48^{\circ} 19^{\prime} 82^{\prime \prime}$ $\mathrm{N}$ and $18^{\circ} 30^{\prime} 50^{\prime \prime} \mathrm{E}$;

5. sampling site - below the water reservoir and above the Kozárovce municipality, $48^{\circ} 19^{\prime} 74^{\prime \prime} \mathrm{N}$ and $18^{\circ} 30^{\prime} 50^{\prime \prime} \mathrm{E}$;
6. sampling site - below the Kozárovce municipality, $48^{\circ} 18^{\prime}$ $77^{\prime \prime} \mathrm{N}$ and $18^{\circ} 32^{\prime} 25^{\prime \prime} \mathrm{E}$.

The samples were used to determine sodium and potassium concentrations (using flame photometry). To evaluate the quality of surface water regarding the sodium indicator, we used the $90^{\text {th }}$ percentile value (P90) based on the recorded values and the following comparison with the corresponding system of limit values that are specified in the Regulation of the Government of the Slovak Republic No. 269/2010 Coll. The potassium indicator values are not stated in said regulation.

Statistical evaluation was realised using the SAS statistical system. Basic statistical characteristics of individual value sets were calculated for both evaluated indicators (table 3). The analysis of variance was based on three qualitative factors (the year, month and site of sampling) (table 4).

\section{Results and discussion}

From the quantitative point of view, the most frequent monovalent basic cation in the Čaradice Stream is sodium. In comparison to potassium, the average concentration of sodium is $30.78 \%$ higher. The average concentration of sodium in 2005-2010 varied from 12.68 (2009) to 18.29 mg.dm ${ }^{-3}$ (2008) and in the whole reference period, it reached $14.75 \mathrm{mg}^{-\mathrm{dm}^{-3}}$ (Figure 1). Higher values of sodium were recorded by Dubová (1998) in the canal Dendeš $\left(46.76 \mathrm{mg}^{-\mathrm{dm}^{-3}}\right)$, Noskovič et al. (2007) in the river Kadaň

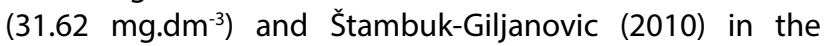
streams Klokun (17.60 mg.dm ${ }^{-3}$ ) and Šilovka (21.0 mg.dm ${ }^{-3}$ ) in Dalmatia. However, the lowest average concentration (12.32 $\mathrm{mg} \mathrm{dm}^{-3}$ ) was recorded by Noskovič et Sozanský (2003) in the stream Hostiansky potok. The share of sodium in the total amount of monovalent basic cations of sodium and potassium $\left(\mathrm{mg}^{\mathrm{dm}} \mathrm{dm}^{-3}\right)$ in the Caradice Stream varied from $73.59 \%$ (2009) to $79.62 \%(2005)$ and in the whole reference period, it reached $76.32 \%$ (Table 1 ). The mass ratio of $\mathrm{Na}^{+}: \mathrm{K}^{+}$varied from $2.81: 1$ (2006) to $3.85: 1$ (2005) and in the whole reference period, it represented $3.34: 1$ (Table 2). Seasonality did not affect the dynamics of sodium concentrations.

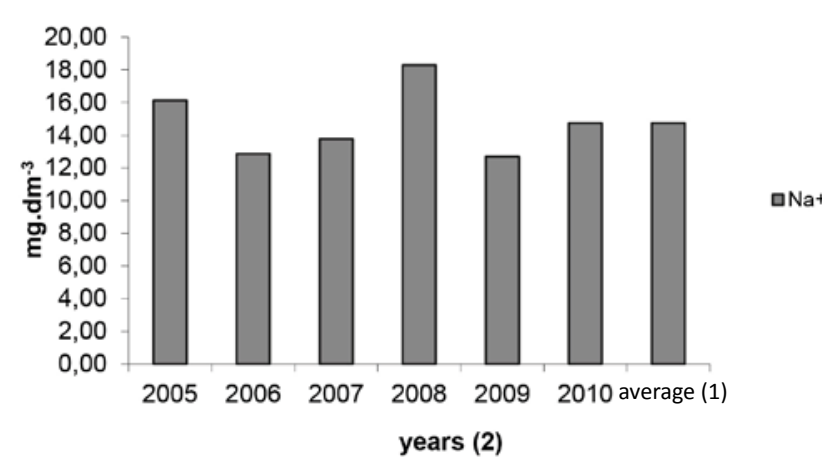

Figure 1 The average concentration of $\mathrm{Na}^{+}$in $\mathrm{mg}^{-\mathrm{dm}^{-3}}$ in the years 2005-2010

Obrázok 1 Priemerná koncentrácia $\mathrm{Na}^{+} \mathrm{v}$ mg.dm ${ }^{-3} \mathrm{v}$ rokoch 2005-2010

(1) priemer, (2) roky 
Table 1 The share of individual cations in the total amount of monovalent basic cations

\begin{tabular}{|l|c|c|c|}
\hline \multirow{2}{*}{ Year (1) } & \multirow{2}{*}{$\begin{array}{c}\text { Total of } \mathbf{~} \mathbf{~ a}^{+}+\mathbf{K}^{+} \\
\mathbf{i n ~} \mathbf{~} \mathbf{d} \cdot \mathbf{d m}^{-\mathbf{3}} \mathbf{( 2 )}\end{array}$} & \multicolumn{2}{|c|}{ The share of individual cations in the total of $\mathbf{~ N a}^{+}+\mathbf{K}^{+} \mathbf{( 3 )}$} \\
\cline { 3 - 4 } & 20.27 & 79.62 & 20.38 \\
\hline 2005 & 17.35 & 74.12 & 25.88 \\
\hline 2006 & 17.90 & 76.87 & 23.13 \\
\hline 2008 & 23.66 & 77.30 & 22.70 \\
\hline 2009 & 17.23 & 73.59 & 26.41 \\
\hline 2010 & 19.30 & 76.43 & 23.52 \\
\hline Average value (4) & 19.29 & 76.32 & 23.68 \\
\hline
\end{tabular}

Tabulka 1 Podiel jednotlivých katiónov na celkovej sume jednomocných bázických katiónov

(1) rok, (2) suma $\mathrm{Na}^{+}+\mathrm{K}^{+} v \mathrm{mg} \cdot \mathrm{dm}^{-3}$, (3) percentuálny podiel jednotlivých katiónov na sume $\mathrm{Na}^{+}+\mathrm{K}^{+}$, (4) priemerná hodnota

Table 2 The mass ratios of individual monovalent basic cations

\begin{tabular}{|l|c|}
\hline \multirow{2}{*}{ Year (1) } & Basic cation ratios (2) \\
\cline { 2 - 2 } & $\mathbf{N a}^{+}: \mathbf{K}^{+}$ \\
\hline 2005 & $3.85: 1$ \\
\hline 2006 & $2.81: 1$ \\
\hline 2007 & $3.41: 1$ \\
\hline 2008 & $3.37: 1$ \\
\hline 2009 & $3.32: 1$ \\
\hline 2010 & $3.28: 1$ \\
\hline Average value (3) & $3.34: 1$ \\
\hline
\end{tabular}

Tabulka 2 Hmotnostné pomery medzi jednotlivými jednomocnými bázickými katiónmi

(1) rok, (2) pomery bázických katiónov, (3) priemerná hodnota

Depending on the time of sampling, the lowest average sodium concentration of the whole reference period was recorded in the spring season with the minimum value in March (10.43 mg.dm ${ }^{-3}$ ) (Figure 2). This decrease was probably caused by higher discharge rates of water in the stream (Figure 3). Since March, the sodium concentration gradually increased and reached its maximum value in September (17.32 mg.dm ${ }^{-3}$ ). The increase of sodium concentration in summer was probably caused by a lower

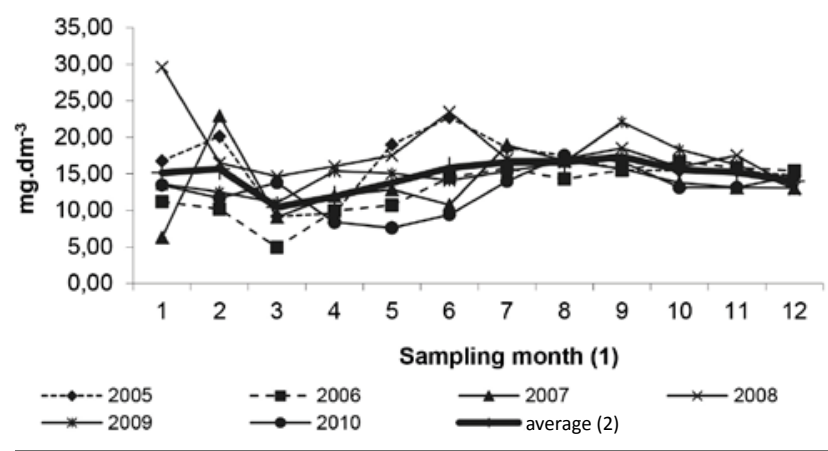

Figure 2 The average concentration of $\mathrm{Na}^{+}$in $\mathrm{mg} \cdot \mathrm{dm}^{-3}$ depending on the sampling time

Obrázok 2 Priemerná koncentrácia $\mathrm{Na}^{+} \mathrm{v}$ mg.dm ${ }^{-3} \mathrm{v}$ závislosti od mesiaca odberu

(1) mesiac odberu, (2) priemer
Table 3 Basic statistical characteristics of selected indicators

\begin{tabular}{|l||c|c|}
\hline Indicator (1) & $\mathbf{N a}^{+}$ & $\mathbf{K}^{+}$ \\
\hline \hline Unit of measurement (2) & $\mathrm{mg} \cdot \mathrm{dm}^{-3}$ & $\mathrm{mg}^{-3} \mathrm{dm}^{-3}$ \\
\hline Arithmetic mean (3) & 14.750 & 4.5426 \\
\hline Statistical error (4) & 0.291 & 0.110 \\
\hline Median (5) & 15 & 4.1 \\
\hline Modus (6) & 15 & 2.5 \\
\hline Standard deviation (7) & 6.007 & 2.278 \\
\hline Variance (8) & 36.088 & 5.190 \\
\hline Coefficient of variation (9) & $40.67 \%$ & $51.47 \%$ \\
\hline Variation range (10) & 49.6 & 13.3 \\
\hline Minimum & 1.2 & 0.2 \\
\hline Maximum & 41.6 & 11.9 \\
\hline
\end{tabular}

Tabulka 3 Základné štatistické charakteristiky vybraných ukazovatelov

(1) ukazovatel', (2) jednotka, (3) aritmetický priemer, (4) štatistická chyba, (5) medián, (6) modus, (7) smerodajná odchýlka, (8) rozptyl, (9) variačný koeficient, (10) variačné rozpätie

discharge rate of water in the Čaradice Stream. In the winter season, the highest average sodium concentration of the whole reference period was recorded in February $(15.65 \mathrm{mg}$.

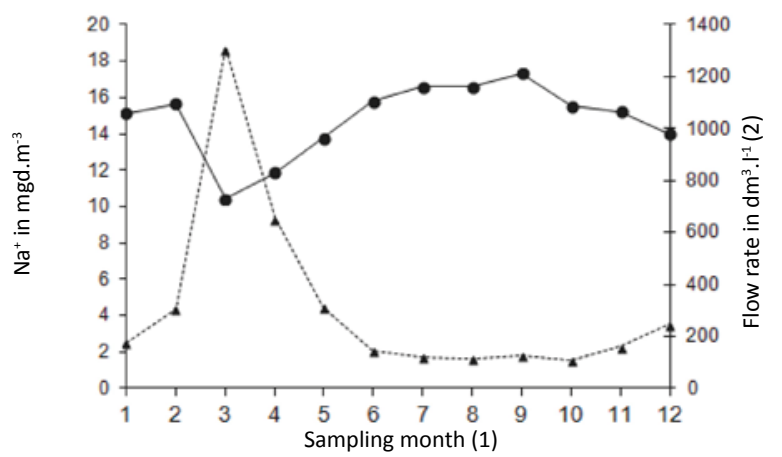

Figure 3 The relationship between $\mathrm{Na}^{+}$concentration in $\mathrm{mg} \cdot \mathrm{dm}^{-3}$ and the discharge rate

Obrázok 3 Vztah medzi koncentráciou $\mathrm{Na}^{+} v$ mg.dm ${ }^{-3}$ a prietokom vody $\mathrm{v} \mathrm{dm}^{3} . .^{-1}$

(1) mesiac odberu, (2) prietok vody $v \mathrm{dm}^{3} . .^{-1}$ 
Table 4 ANOVA - Analysis of variance for $\mathrm{Na}^{+}$and $\mathrm{K}^{+}$

\begin{tabular}{|l|c|c|c|c|c|c|}
\hline \multicolumn{7}{|c|}{ One-dimensional test of significance for Na $\mathbf{~}^{(1)}$} \\
\hline \multicolumn{2}{|l|}{ Effect (2) } & Sum of squares (3) & Degree of freedom (4) & Variance (5) & F value (6) & P value (7) \\
\hline \multirow{2}{*}{ Absolute term (8) } & $\mathrm{Na}^{+}$ & 92607.14 & 1 & 92607.14 & 3860.698 & 0.000000 \\
\cline { 2 - 8 } & $\mathrm{K}^{+}$ & 8311.575 & 1 & 8311.575 & 2649.99 & 0.000000 \\
\hline \multirow{3}{*}{ Year (9) } & $\mathrm{Na}^{+}$ & 1556.78 & 5 & 311.36 & 12.98 & 0.000000 \\
\cline { 2 - 8 } & $\mathrm{K}^{+}$ & 92.937 & 5 & 18.587 & 5.9526 & 0.000027 \\
\hline \multirow{3}{*}{ Month (10) } & $\mathrm{Na}^{+}$ & 1509.11 & 11 & 137.19 & 5.98 & 0.000000 \\
\cline { 2 - 8 } & $\mathrm{K}^{+}$ & 190.972 & 11 & 17.361 & 5.535 & 0.000000 \\
\hline \multirow{3}{*}{ Place (11) } & $\mathrm{Na}^{+}$ & 2437.57 & 5 & 48751 & 5.719 & 0.000000 \\
\cline { 2 - 8 } & $\mathrm{K}^{+}$ & 636.223 & 5 & 127.245 & 40.57 & 0.000000 \\
\hline \multirow{2}{*}{ Error (12) } & $\mathrm{Na}^{+}$ & 960.81 & 404 & 23.99 & 20.324 & - \\
\cline { 2 - 8 } & $\mathrm{K}^{+}$ & 1267.128 & 404 & 3.136 & 1.98 & - \\
\hline
\end{tabular}

Tabulka 4 ANOVA - Analýza rozptylu pre $\mathrm{Na}^{+}$a $\mathrm{K}^{+}$

(1) jednorozmerný test významnosti pre $\mathrm{Na}^{+}$, (2) efekt, (3) súčet štvorcov, (4) stupeň volinosti, (5) rozptyl, (6) hodnota F, (7) preukaznost', (8) absolútny člen, (9) rok, (10) mesiac, (11) miesto, (12) chyba

$\mathrm{dm}^{-3}$ ). Roger (2008) claims that this is caused by road salt that is used for road maintenance, as it is a significant source of sodium in streams and rivers.

Depending on the sampling site, the average concentration of sodium was gradually increasing with the increasing length of the stream (Figure 4). The lowest average concentrations of the whole reference period were recorded at the first two sampling sites (below the forest ecosystem and the ecosystem of permanent grasslands). The maximum average concentration of the whole reference period was detected at the sampling site No. 6 (below the municipality Kozárovce). The most significant increase of sodium concentration was also recorded here. The second largest increase was recorded at the sampling site No. 3 (below the municipality Čaradice). The increase recorded below municipalities was probably caused by the fact that sodium got into the stream through uncleansed sewage, as the municipalities did not have sewage treatment plants. Veselý et al. (2001) claim that higher levels of sodium in surface water are connected with urbanization and higher population density in the vicinity of the stream, as these factors can significantly worsen the quality of water and the salinity of water ecosystems.

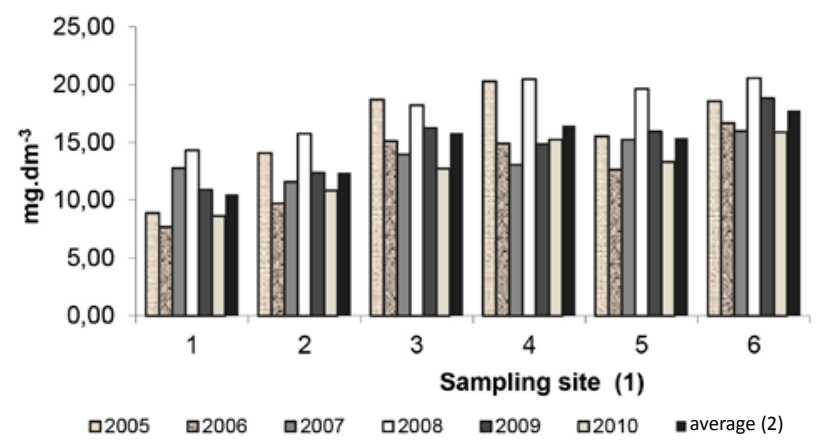

Figure 4 The average concentration of $\mathrm{Na}^{+}$in $\mathrm{mg} \cdot \mathrm{dm}^{-3}$ depending on the sampling site

Obrázok 4 Priemerná koncentrácia $\mathrm{Na}^{+} \mathrm{v}$ mg.dm ${ }^{-3} \mathrm{v}$ závislosti od miesta odberu

(1) miesto odberu, (2) priemer
The analysis of variance showed a statistically significant effect of all three qualitative factors (year, month and sampling site) on the change of sodium concentrations (Table 4). This was also confirmed by the highly significant correlation dependence between the observed monovalent basic cations (Table 5).

According to the Regulation of the Government of the Slovak Republic No. 269/2010 Coll, the recommended value for sodium $100 \mathrm{mg} \mathrm{dm}^{-3}$. The detected $90^{\text {th }}$ percentile values for this indicator are lower than the recommended value.

Compared to sodium, the potassium concentration was lower. According to Pitter (1999), this is connected with a more intense biological, physical and chemical sorption of potassium in the soil. Barančíková et al. (2009) claim that a lower potassium concentration can also be caused by the fact that potassium is an important nutrient for plants. Its average concentration in the reference years varied from 4.13 (2005) to $5.37 \mathrm{mg}^{-\mathrm{dm}^{-3}}$ (2008). In the whole reference period, it reached $4.54 \mathrm{mg}^{-\mathrm{dm}^{-3}}$ (Figure 5). Similarly to sodium, seasonality did not affect the dynamics of potassium concentration. The average potassium concentration in the whole reference period was higher than detected by Noskovič et al. (2009) in the stream Čerešňový

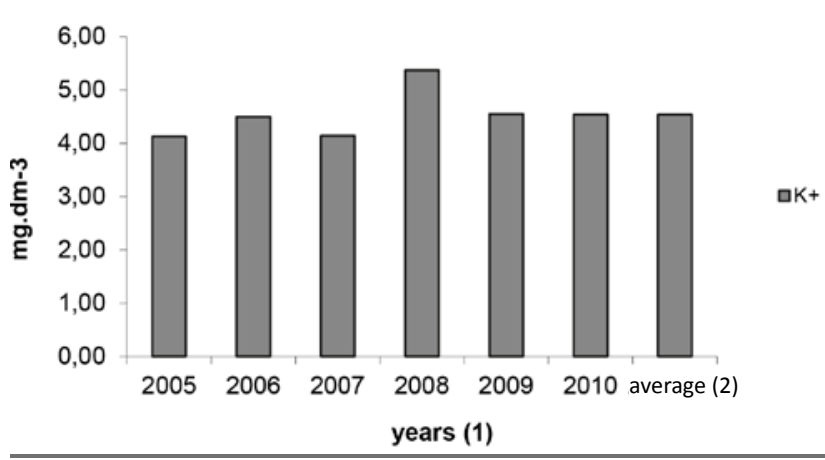

Figure 5 The average concentration of $\mathrm{K}^{+}$in $\mathrm{mg} \cdot \mathrm{dm}^{-3}$ in the years 2005-2010

Obrázok 5 Priemerná koncentrácia $\mathrm{K}^{+} \mathrm{v}$ mg.dm ${ }^{-3}$ počas rokov 2005-2010

(1) roky, (2) priemer 


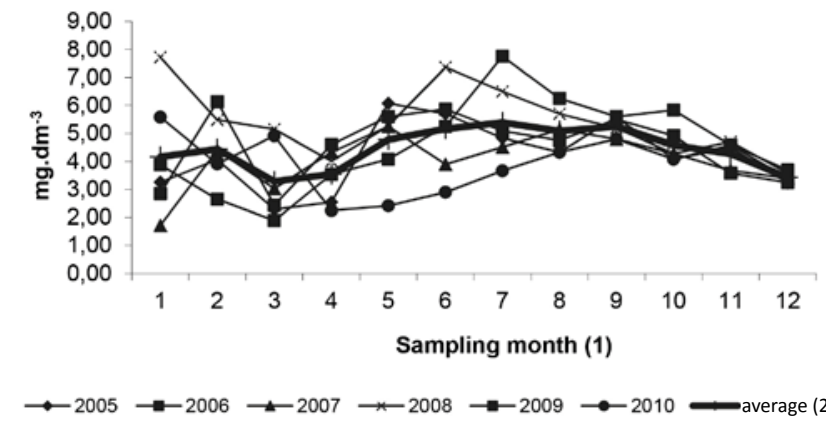

Figure 6 The average concentration of $\mathrm{K}^{+}$in $\mathrm{mg} \cdot \mathrm{dm}^{-3}$ depending on the sampling time

Obrázok 6 Priemerná koncentrácia $\mathrm{K}^{+} \mathrm{v}$ mg.dm ${ }^{-3} \mathrm{v}$ závislosti od času odberu

(1) mesiac odberu, (2) priemer

Table 5

Correlations for $\mathrm{Na}^{+}$and $\mathrm{K}^{+}$

\begin{tabular}{|l|c|c|c|}
\hline \multicolumn{2}{|l|}{ Correlations (1) } & $\mathbf{N a}^{+}$ & $\mathbf{K}^{+}$ \\
\hline \multirow{3}{*}{$\mathrm{Na}^{+}$} & Pearson Correlation & 1 & 0.660 \\
\cline { 2 - 4 } & Sig. (2-tailed) & & $\mathrm{XXX}(1)$ \\
\cline { 2 - 4 } & $\mathrm{N}$ & 426 & 426 \\
\hline \multirow{3}{*}{$\mathrm{K}^{+}$} & Pearson Correlation & 0.660 & 1 \\
\cline { 2 - 4 } & Sig. (2-tailed) & $\mathrm{XXX}(1)$ & \\
\cline { 2 - 4 } & $\mathrm{N}$ & 426 & 426 \\
\hline
\end{tabular}

Signifikancia: vysoko významné

Significance: highly significant

Tabulka 5 Korelácie pre $\mathrm{Na}^{+}$a K

(1) korelácie

potok (2.74 mg.dm $\mathrm{m}^{-3}$ and lower than detected by Baert et al. (1996) in the streams Roesbrugge $\left(16.8 \mathrm{mg}^{-\mathrm{dm}^{-3}}\right)$, Stavele (20.8 mg. dm ${ }^{-3}$ ) and Kemmel brook (25.5 mg. $\left.\mathrm{dm}^{-3}\right)$ in Belgium and by Noskovič et al. (2010) in Žitavský luh $\left(8.30 \mathrm{mg}^{-3} \mathrm{dm}^{-3}\right)$. The share of potassium cations in the whole amount of monovalent basic cations of $\mathrm{Na}^{+}+\mathrm{K}^{+}\left(\mathrm{mg}^{-\mathrm{dm}^{-3}}\right)$ in the Čaradice Stream varied from 20.38 (2005) to $26.41 \%$ (2009) and in the whole reference period, it reached $23.68 \%$ (Table 1 ).

Depending on the sampling time, the minimum average potassium concentrations were recorded in the spring season and the maximum concentrations were recorded in summer. The lowest average concentration of the whole period was recorded in March $\left(3.29 \mathrm{mg}^{-\mathrm{dm}^{-3}}\right.$ ) and the highest average concentration in July $\left(5.39 \mathrm{mg}^{-\mathrm{dm}^{-3}}\right.$ ) (Figure 6). By analogy with the sodium cations, we can assume that the decrease in potassium concentration in the spring season was caused by higher discharge rates of the stream (Figure 7).

Potassium concentrations in the longitudinal profile of the stream were affected by the sampling site. During the reference period, the minimum average concentration was recorded at the sampling site No.1 (2.82 mg.dm ${ }^{-3}$ ) located below a forest ecosystem (Figure 8 ). Similarly to sodium concentrations, a significant increase in potassium concentration was detected below the municipalities of Čaradice (sampling site No. 3) and Kozárovce (sampling site No. 6). The maximum average concentration of the whole period was detected at the sampling site No. $6\left(6.06 \mathrm{mg}_{\mathrm{dm}} \mathrm{dm}^{-3}\right.$ ). The increase of potassium concentration below urban ecosystems of streams like Kadaň and Čerešňový potok was recorded by Noskovič et al. $(2007,2009)$.

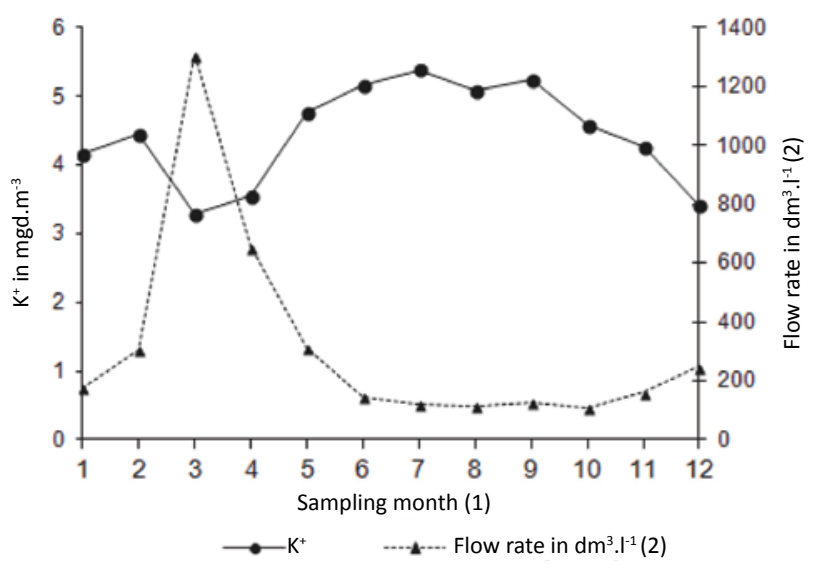

Figure 7 The relationship between the $\mathrm{K}^{+}$concentration in mg. $\mathrm{dm}^{-3}$ and the discharge rate in $\mathrm{dm}^{3} . \mathrm{I}^{-1}$

Obrázok 7 Vzt’ah medzi koncentráciou $\mathrm{K}^{+} \mathrm{v}$ mg.dm ${ }^{-3}$ a prie-

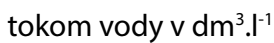

(1) mesiac odberu, (2) prietok vody $v \mathrm{dm}^{3} .^{-1}$

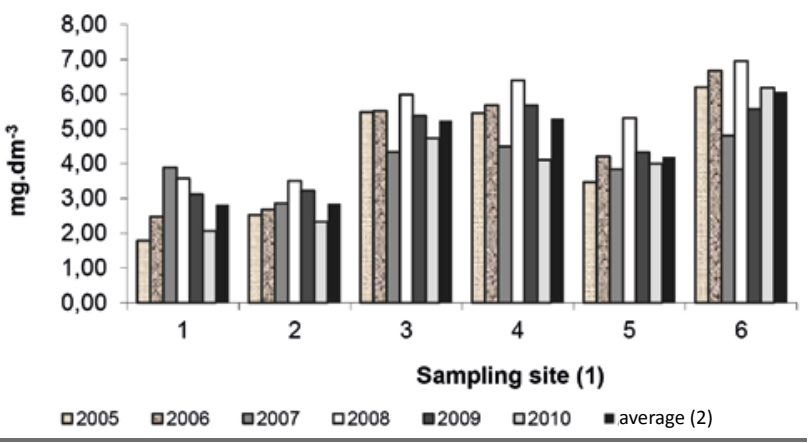

Figure 8 The average $\mathrm{K}^{+}$concentrations in $\mathrm{mg}^{-\mathrm{dm}^{-3}} \mathrm{de}-$ pending on the sampling site

Obrázok 8 Priemerné koncetrácie $\mathrm{K}^{+} \mathrm{v} \mathrm{mg} \mathrm{dm}^{-3} \mathrm{v}$ závislosti od miesta odberu

(1) miesto odberu, (2) priemer

The analysis of variance proved that all three qualitative factors (year, month and sampling site) have a statistically significant effect on the change of potassium concentration (table 4). The recommended value for potassium is not specified in the Regulation of the Government of the Slovak Republic No. 269/2010 Coll.

\section{Súhrn}

V rokoch 2005 - 2010 sa hodnotili zmeny koncentrácie jednomocných bázických katiónov vo vodnom toku Čaradický potok v závislosti od času a miesta odberu v jeho pozdlžnom profile. Z výsledkov vyplýva, že priemerná koncentrácia $\mathrm{Na}^{+}$ za celé sledované obdobie bola $14,75 \mathrm{mg} \mathrm{dm}^{-3}$. Jeho podiel na celkovej sume jednomocných bázických katiónov $\mathrm{Na}^{+}+$ $\mathrm{K}^{+}$za celé sledované obdobie reprezentoval 76,32 \%. Hmotnostný pomer $\mathrm{Na}^{+}: \mathrm{K}^{+}$za celé sledované obdobie bol 3,34:1. V závislosti od času odberu sa najnižšie priemerné koncentrácie $\mathrm{Na}^{+}$za celé pokusné obdobie zaznamenali $v$ jarnom období, s minimálnou priemernou hodnotou $v$ mesiaci marec. Najvyššia priemerná koncentrácia za celé sledované obdobie sa zistila $v$ mesiaci september. $V$ závislosti od miesta odberu sa jeho minimálna priemerná koncentrácia 
zistila pod lesným ekosystémom a ekosystémom trvalých trávnych porastov, maximálna pod obcou Kozárovce. Analýzou rozptylu sa zistil štatisticky významný vplyv všetkých troch kvalitatívnych faktorov (rok, mesiac a miesto odberu) na zmenu jeho koncentrácie. Podla nariadenia vlády SR č. 269/2010 Z. Z., hodnoty 90-teho percentilu tohto ukazovatel'a sú nižšie ako odporúčaná hodnota. Priemerná koncentrácia draslíka za celé sledované obdobie bola 4,54 mg. $\mathrm{dm}^{-3}$. Podiel $\mathrm{K}^{+}$na celkovej sume jednomocných bázických katiónov za celé sledované obdobie reprezentoval 23,68\%. Najnižšie priemerné koncentrácie za celé sledované obdobie sa zistili spravidla v jarnom období, s minimálnou hodnotou v mesiaci marec. Maximálna priemerná koncentrácia za celé sledované obdobie bola v mesiaci júl. Podobne ako pri $\mathrm{Na}^{+}$, najnižšia priemerná koncentrácia $\mathrm{K}^{+}$sa zistila $\mathrm{v}$ lesnom ekosystéme a najvyššia pod obcou Kozárovce. Sezónna zákonitost' dynamiky koncentrácie $\mathrm{Na}^{+}$a K $\mathrm{K}^{+}$sa v priebehu sledovaného obdobia neprejavila. Analýzou rozptylu sa zistil štatisticky významný vplyv všetkých troch kvalitatívnych faktorov (rok, mesiac a miesto odberu) na zmenu ich koncentrácie. V nariadení vlády SR č. 269/2010 Z. z. pre draslík nie je odporúčaná hodnota uvedená. Na zmeny koncentrácie $\mathrm{Na}^{+}$a $\mathrm{K}^{+}$vo vodnom toku výrazne participoval prietok vody.

Klúčové slová: vodný tok, jednomocné bázické katióny, sodík, draslík

\section{Acknowledgement}

This research was supported from the grant projects VEGA 1/0457/08 and VEGA 1/0513/12.

\section{References}

BARANČíKOVÁ, G. - FAZEKAŠOVÁ, D. - MANKO, P. - TORMA, S. 2009. Chémia životného prostredia. Prešov : Prešovská univerzita. 2009, 255 s. ISBN 978-80-555-00829-9.

BEARD, D. R. - ROBERT, S. C. 1996. Potassium and nitrate pollutation of surface water in the catchment area of the Blankeart. (online) dostupné na internete: http://www.inece.org/4thvol2/baert.pdf DUBOVÁ, M. 1998. Chemizmus vody v kanáli Dendeš v PR Chynoranský luh. In: Folia oecologica, roč. 24, 1998, s. 103-112.

HRUŠKA, J. - MAJER, V. - FOTTOVÁ, D. 2006. Vliv kyselé depozice na chemismus povrchových vod v Krkonoších. In: Opera Corcontica, 2006, č. 43, s. 95-110. ISSN 1803-1412.

KAŠIAROVÁ, S. 2002. Kontaminácia ekosystémov. Banská Štiavnica, 2002, 50 s. ISBN 978-80-228-1836-0.
KONEČNÝ, V. 1998. Vysvetlivky ku geologickej mape Štiavnických vrchov a Pohronského Inovca (štiavnické stratovulkány). Geologická služba Slovenskej republiky. Bratislava : Vydavatel'stvo Dionýza Štúra, 1998, $473 \mathrm{~s}$.

NARIADENIE vlády Slovenskej republiky 269/2010, ustanovujúce požiadavky na dosiahnutie dobrej kvality vôd.

NOSKOVIČ, J. - SOZANSKÝ, P. 2003. Evalution of bivalent and univalent alkaline cations concentrations in a water course in the Tribeč Mountains. In: Folia oecologica, vol. 30, 2003c, no. 1, p. 87-97. ISBN 80-967238-2-0.

NOSKOVIČ, J. - BABOŠOVÁ, M. - SZOMBATHOVÁ, N. 2007. Hodnotenie koncentrácie bázických katiónov vo vodnom toku Kadaň v povodí rieky Nitra. In: Acta hydrologica Slovaca, roč. 8, 2007, č. 2, s. 143-152. ISSN 1335-6291.

NOSKOVIČ, J. - PALATICKÁ, A. - KALÚZ, K. - RÁKOVSKÁ, A. 2009. Koncentrácie bázických katiónov vo vodnom toku Čerešňový potok. In: Acta hydrologica Slovaca, roč. 10, 2009, č. 1, s. 25-34. ISSN 1335-6291.

NOSKOVIČ, J. - BABOŠOVÁ, M. - KVETANOVÁ, L. 2010. Hodnotenie koncentrácie dvojmocných bázických katiónov vo vode prírodnej rezervácie Alúvium Žitavy. In: Acta hydrologica Slovaca, roč. 11, 2010, č. 1, s. 97-107. ISSN 1335-6291.

OROLÍNOVÁ, M. 2009. Chémia a životné prostredie. Trnava, 2009, 122 s. ISBN 978-80-8082-298-9.

PAČES, T. 2011. Úvod do hydrochemie. TU Praha - Liberec, 2011, s. 79. PITTER, P. 1999. Hydrochemie. Praha : VŠCHT, 1999. 568 s. ISBN 80-7080-340-1.

PITTER, P. 2009. Hydrochemie. $4^{\text {th }}$ ed. Praha : VŠCHT, 2009. ISBN 978-80-7080-701-9.

ROGER, E. 2008. Sodium and chloride contamination in Loantaka. Great Swamp Watershed Association. In: Journal Hydrology, vol. 8, 2008, p. 34-86. ISBN 978-80-228-17-60-8

ŠTAMBUK - GILJANOVIC. 2010. Sodium Levels in the Spring Water, Surface and Groundwater in Dalmatia (Southern Croatia). Water Quality Monitoring and Assessment, 2010, p. 269-281. ISBN 978-953-51-0486-5.

TÖLGYESSY, J. - MELICHOVÁ, Z. 2000. In: Chémia vody (voda a jej ochrana). Banská Bystrica: UMB, 2000, 154 s. ISBN 80-8055-293.

VESELÝ, J. - MAJER, V. - KUČERA, J. - HAVRÁNEK, V. 2001. Solid-water partitioning of elements in Czech freshwaters. In: Appl. Geochem., 2001, no. 16 , p. 437-450.

\section{Contact address:}

doc. Ing. Jaroslav Noskovič, CSc., Department of Environmental Sciences and Zoology, Faculty of Agrobiology and Food Resources, Slovak University of Agriculture in Nitra, Tr. Andreja Hlinku 2, 94976 Nitra, phone: +421/37/641 44 22, +421/37/641 43 15, e-mail: Jaroslav.Noskovic@uniag.sk 